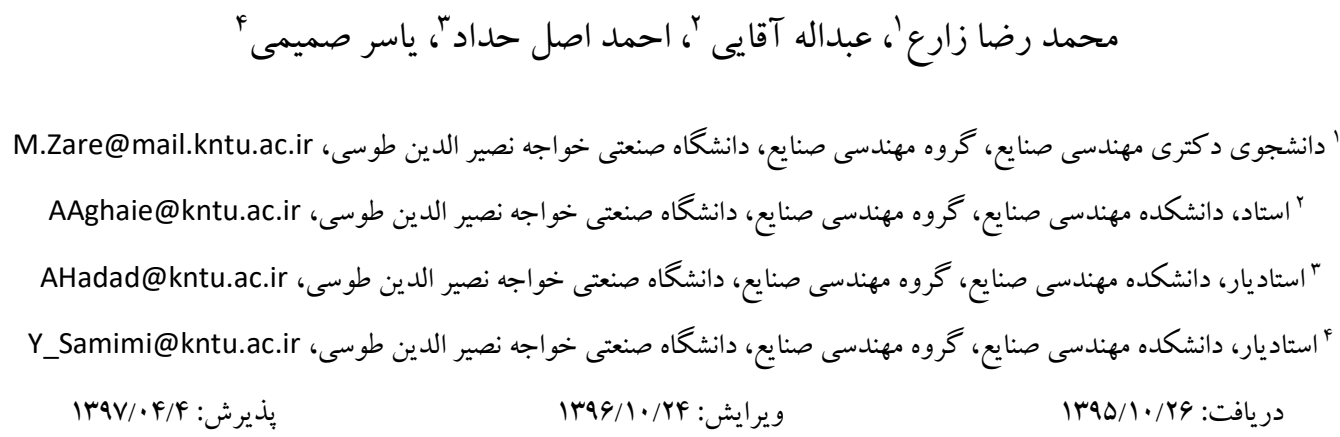

\title{
Service Quality Management Modeling, Controlling and Upgrading as well as Communications and Information Technology Enhancement through Conducting a Case Study in the Parent Telecommunications Network of Iran
}

Mohammad Reza Zare, Abdollah Aghaie, Ahmad Asl Hadad, Yaser Samimi

Abstract: This paper reviews the service quality management control and upgrade as well as the communications and information technology enhancement. The purpose of this research is the control and improvement of the service quality management as well as the enhancement of the parent telecommunications network of I.R.Iran that finally, taking the specific conditions into consideration, the quality management service model of the telecommunications parent network of Iran will precisely be used as the whole in the format of the communications and information technology enhancement model after identifying and specifying the levels of the relationships existing among the models, and the standards of the communications and information technology management. The study shows developing such a model in the industry of ICT with emphasis and establishment in the parent telecommunications network of Iran, benefit of human capital with the latest technology and presenting modern services to the customers, the service quality management will be upgraded and will lead to the improvement in quality management in the field of ICT.

Keywords: Control, Service Quality Management, Parent Telecommunications Network, Standards, Excellence Models. 
ها يشان را بر روى مشتريان و ذى نفعان خود متمر كز كنند. به همين منظور

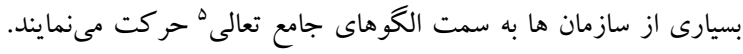

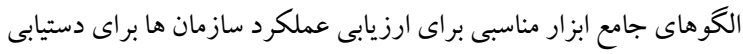
به سطوح مختلف تعالى مىباشند.

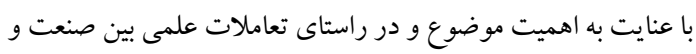

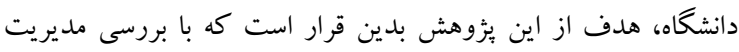

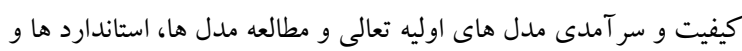

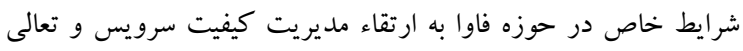

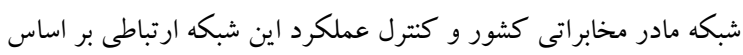
مشترى محورى دست يابيم.

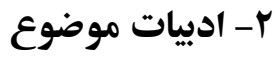

ارتقاء كيفيت سرويس و محصول براى موفقيت در بازارهاى جهانى

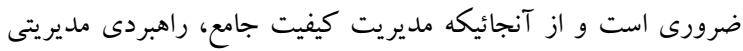

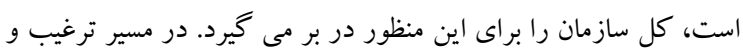

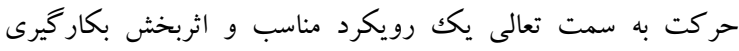

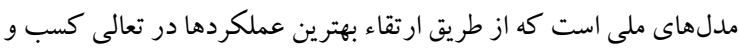
كار و ايجاد فرصت براى ارتقاء مستمر، اثر ات مثبتى بر رشد اقتصادى دارند

استفاده از مدل هاى تعالى در دهه اخير بسيار رواج يافته و شركتهاى

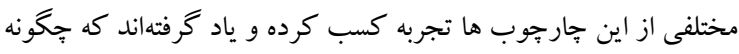

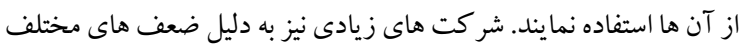
اين مدل ها مانند معيار هاى ارزيابى بيجيده، تشريفات ادارى بيش از حد،

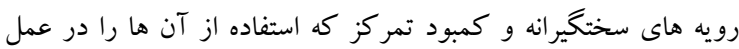

محدود نموده است، به مشكلاتى برخورد كرده اند [2].

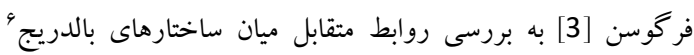

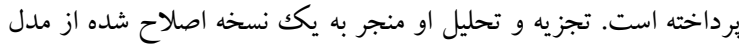

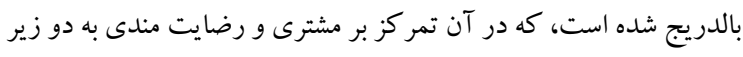
مجموعه تقسيم شده است. يافته ها بر بايه حمايت از تاثير رهبرى بر بر تمام

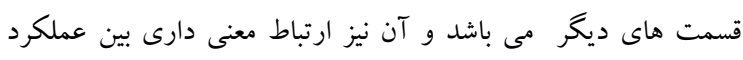

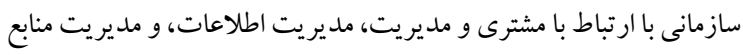

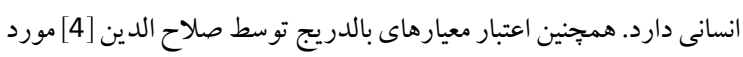

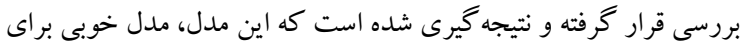

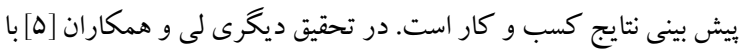

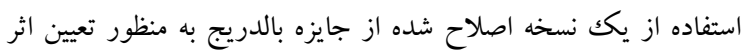

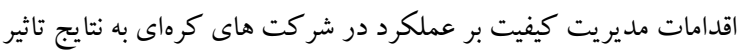

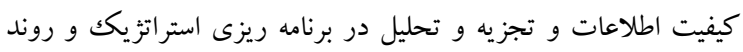
مديريت كيفيت برداخته اند. مديريت منابع انسانى و مديريت فرين لريند مهري
1 - مقدمه

ارتباطات و فناورى اطلاعات بعنوان اصلى ترين و تأثير گذار ترين

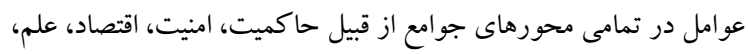

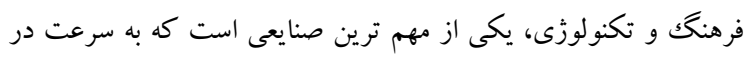

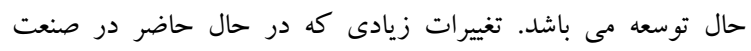

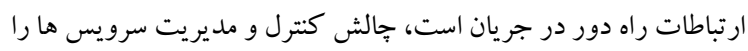
با كيفيت بالا بيجيده ساخته است. كيفيت وازه رايج و آشنايى است كه از مفهوم و نحوه كاربرد آن آن

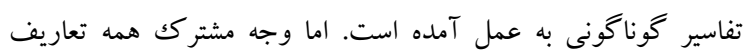

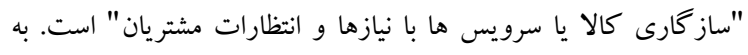
عبارت ديخر كيفيت وقتى به دست مى آيد كه سرويس يا محصول،

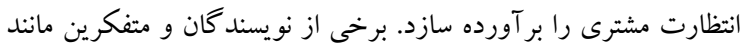

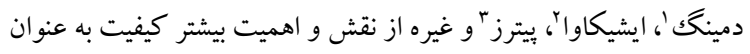
مبنا و سنكَ بناى اصلى تعالى حمايت كرده اند. سازمانهاى امروز، با جهانى شدن بازارها و تغييرات سريع در اقتصاد

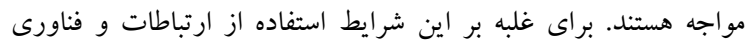
اطلاعات لازم و ضرورى است، از اين رو ارتباطات و فناورى اطلاعات ("ICT)

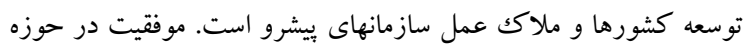

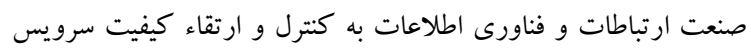

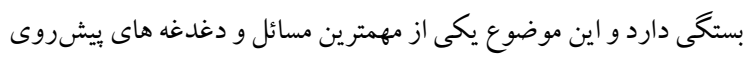
مديران در اين حوزه مى باشد.

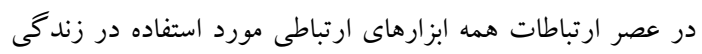

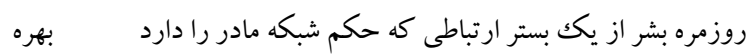

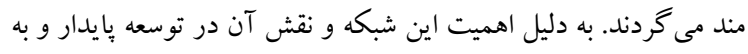

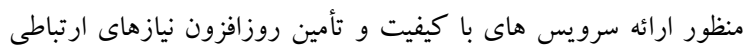
مشتريان و جلب رضايت آنهاو ساير ذى نفعان، حفظ، بهبود مستمر، كنترل

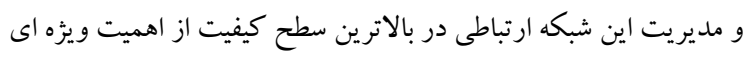
برخوردار است.

شركت ارتباطات زيرساخت به عنوان تنها متولى و مرجع حاكميتى

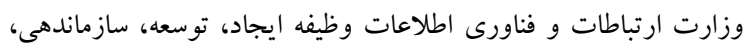
كنترل، نظارت، بهرهبردارى و مديريت سرويس هاى با كيفيت شبكه مادر

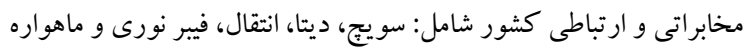
رابه عهلده دارد. كيفيت سرويس ها و محصولات نقش مهم و كليدى در سازمان ها

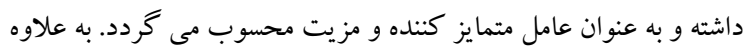

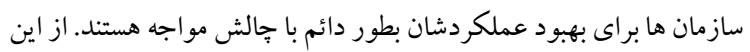

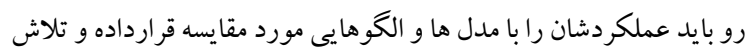

* Information and Communication Technology

'Deming, E.

$\checkmark$ Excellence

Ishikawa, K.

` Malcom Baldrige National Quality Award

r Peters, Th. 


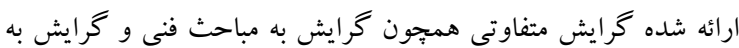

مباحث مدير يتى دارند. برخى از اين مدلها و استاندارد ها عبار تند ازئ Val IT^, COBIT 5 $5^{4}$, ISMS' ', PRINCE $2^{\prime \prime}$, ITBSC' ${ }^{\prime r}$, Framework اغلب كشورها از جارجوب و الكوى بنياد مديريت كيفيت ارويا و

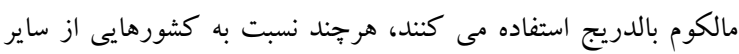
مناطق دنيا، تعداد زيادى تحت تأثير مشاركت زياد، بسيارى از كشورهاى

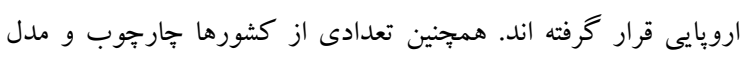

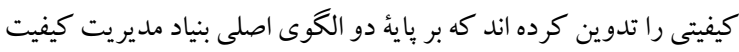

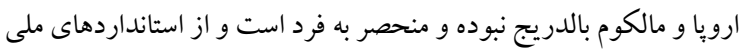

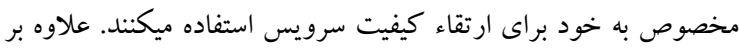

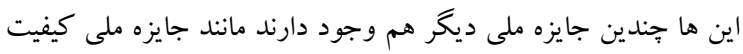

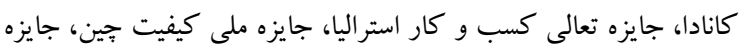
كيفيت نخست وزير در مالزى، جايزه بزرگك كيفيت كره، جايزه كيفيت

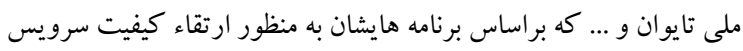

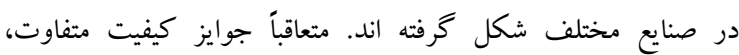
استانداردها يا معيارهاى كيفيت يكسان و يا متفاوت بيشنهاد مى كنند [ [11].

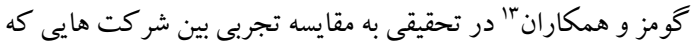

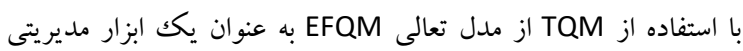

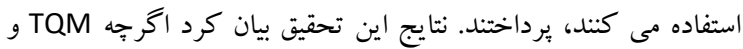

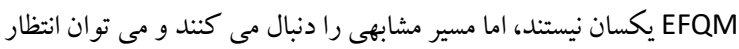

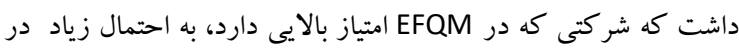

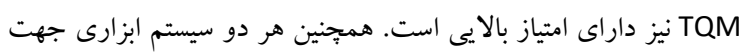

بهبود عملكرد و ارتقاء كيفيت سرويس را فراهم مى آورند [IY]

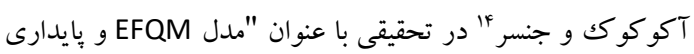

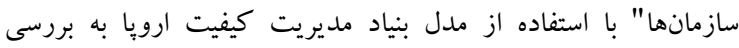

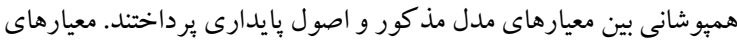
شناسايى شده توسط اين مدل دو دسته هستند شامل توانمندسازها و نتايج. معيارهاى شناسايى شده براى توانمندسازها در اين تحقيق، رهبرى،

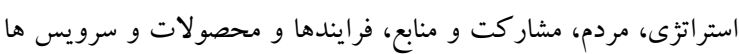
معرفى شده اند. همجنين عوامل نتايج عبار تند از:

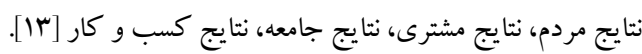

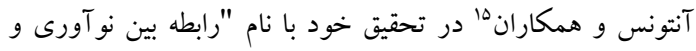

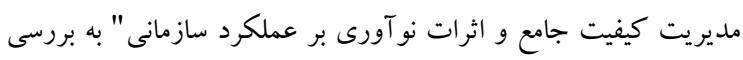

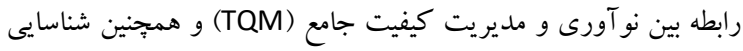
اثرات نو آورى بر عملكرد سازمانى برداختند. يافته هاى اين تحقيق نشان
ترين نتايج كيفى بودند. ساختار بِيجِيده معيارهاى مدل ملى كيفيت ارويا (EFQM')

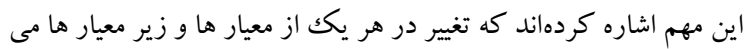

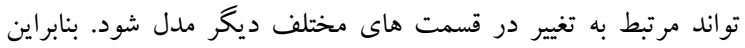

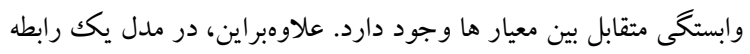

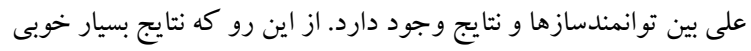

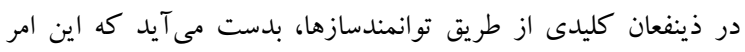
براساس، داشتن رهبرى قوى و جهت گيرى استراتزيكك روشن، توسعه و

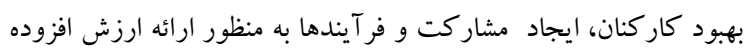
محصو لات و سرويس با كيفيت به مشتريان است [9].

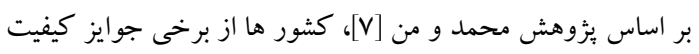

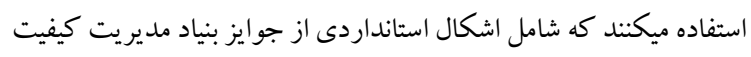
ارويا، مالكوم بالدريج، دمينگ ب و استانداردهاى منحصر به فردى از ديخر

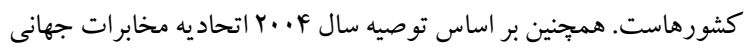

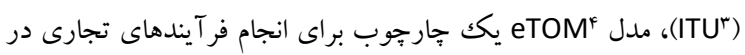

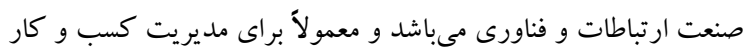

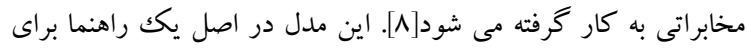

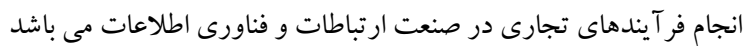

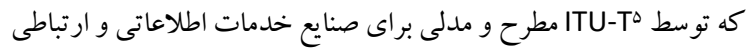

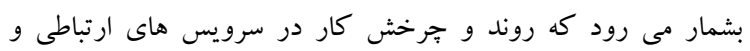

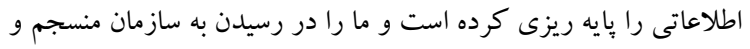

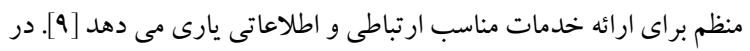
واقع eTOM داراى ץ فاز استراتزيك،، عملياتى و مديريتى به همراه 10

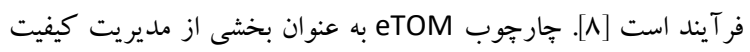

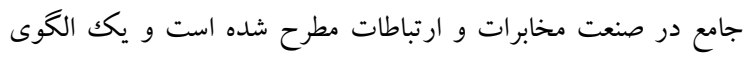

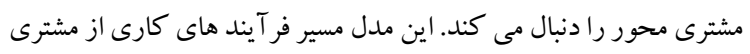

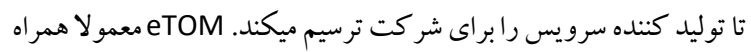

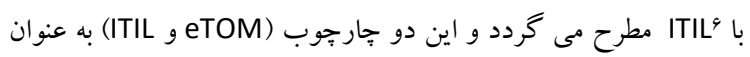
بخشى از مديريت كيفيت جامع (TQM) در صنعت مخابرات و ارتباطات

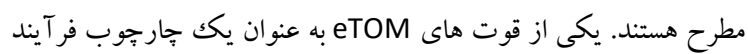

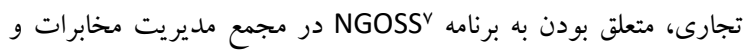

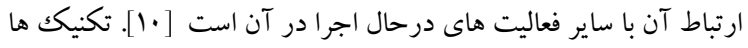

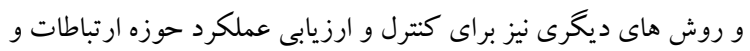

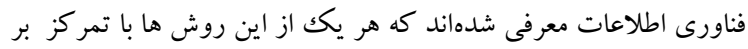

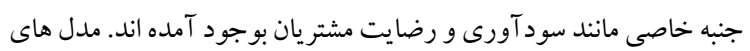

' Control Objectives for Information and Related Technologies 5 - Information Security Management System

' Projects in Controlled Environment 2

ir IT Balanced Scorecard

'r Gomez et al

if Akkucuk \& Gencer

is Antunes et al

\author{
European Foundation for Quality Management \\ Deming Quality Award and Model \\ $r$ International Telecommunication Union \\ * Enhanced Telecom Operations Map \\ $\checkmark$ International Telecommunication Union - Telecom Sector \\ $\checkmark$ IT Infrastructure Library \\ $\checkmark$ Next Generation Operations Support System \\ $\wedge$ Value from IT Investments
}


اختصاص داده شده اند. هدف TL 9000 تعريف الزامات سيستم مديريت كيفيت مورد نياز حوزه ارتباطات و فناورى اطلاعات براى طراحى، توسعه، توليد، و خدمات مى باشد. علاوه بر اين، معيارهايى براى شركت ها براى كمك به ارزيابى اثربخشى اجراى كيفيت و برنامه هاى بهبود مشخص مى كند [19].

يريرا و همكاران’ در تحقيقى با عنوان "قابليت مديريت ارزش

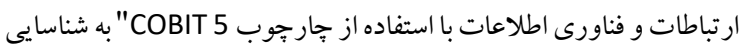
يكك ديد كاه نظرى مبتنى بر منابع يرداختند و مجموعه اى از توانايى ها، منابع و شيوه هايى كه به توسعه و مفهوم سازى يكك مدل قابلتى مديريت ارزش ارتباطات و فناورى اطلاعات مى بردازد را با استفاده جشم اندازى

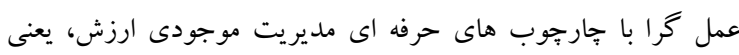
Val IT 2.0 معرفى كردند. طبق اين تحقيق اصول، سياست ها COBIT 5 و جارجوب هاى ارائه شده عبارتند از: فرايندها، ساختار سازمانى، اطلاعات، سرويس ها، زير ساخت ها و برنامه هاى كاربردى، مردم، مهارت ها و توانايى ها، فرهنگك، اخلاق و رفتار [IV]. در مطالعه اى كه توسط يولاكك و كلاينر در خصوص مديريت كيفيت سرويس و تعالى در صنعت مخابرات انجام شد يك نكته مهم شناسايى گرديد كه همه شر كتهاى متعالى در يك زمينه با يكديخر شباهت دارند و آن اين است كه همه آنها آماده تغيير و رشد بوده و ارزشهاى اصلى خود را حفظ مى كنند. به عبارت ديخر آنها از سيستم انخيزش كاركنان خود بهره مى برند و از فعاليت هائى كه باعث از دست دادن تمر كز بر روى هدف اصلى آنها مى شود اجتناب مىورزند. بطور خلاصه شر كتهاى موفق مخابراتى در آينده نياز دارند كه در مسير مديريت كيفيت سرويس و تعالى

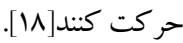

همجينين آصيف خانه در مقاله ى خود به نام "بررسى مدل مديريت دمينگ در صنعت مخابرات كشور باكستان" به بررسى مديريت كيفيت جامع در ياكستان يرداخته است. نتايج نشان دهنده اين موضوع هستند كه در سازمان هايیى كه به خوبى مديريت كيفيت جامع را اجرا مى كنند، از بهينه كاوى " استفاده شده است. او در اين مقاله كه در زمينه ى ارتباطات و فناورى اطلاعات و كيفيت سرويس در حوزه ICT مى باشد، به سازمانهايى اشاره كرده است كه با استفاده از مديريت كيفيت جامع نواقص و كمبودهاى خود را شناسائى كرده و با رقابت يذيرى، بهبود مستمر رادر

سازمان هاى خود اجر ا نموده اند [19]. طالب و رحمان در مطالعه اي كه درحوزه ارتباطات و فناورى اطلاعات كشور هندوستان انجام گرديد معيارهاى كليدى مديريت كيفيت جامع در اين حوزه و شر كتهائى كه در اين زمينه فعاليت دارند، مورد بررسى قرار كرفت. نتيجه كيرى شد كه مديريت ارشد بايد تعهد خود را نسبت به به
مى دهد كه شر كت هايى كه استراتثى هاى نو آورى در فرايند را اتخاذ مى كنند، بهبود عملكرد خود را از لحاظ عملياتى و مالى افز ايش مىدهند، در

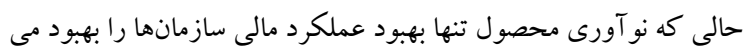
بخشد. از سوى ديخر، مشخص شد كه تنها شر كتهايى كه استراتزى هاى

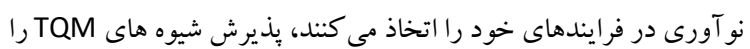
ارتقاء مى دهند و بين نو آورى محصول و اجراى شيوه هاى TQM ارتباط آمارى معنى دارى وجود دارد [If]. اولوناد و اوياتوى' در تحقيق خود با عنوان "ايزو ...9 و بهبود استانداردهاى كيفيت سرويس در واحد هاى نخهدارى شركت هاى توليدى انتخاب شده در LAGOS" به بررسى نقش استاندارد ايزو ...9 به عنوان يكك ابزار براى بهبود استانداردهاى كيفيت سرويس در واحد تعمير و نخهدارى سازمان هاى توليدى لاكس بيرداختند. آنها تصويب استاندارد

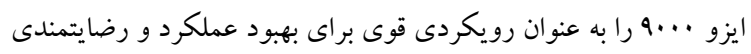
شر كت معرفى كردند. با اين حال شركت هايى كه اين رويكرد را بذيرفته اند سطح عملكرد و موفقيت آنها باهم متفاوت بوده است. نتايج اين تحقيق نشان داد كه تصويب ابزار گو اهينامه كيفيت ايزو ...9 به طور قابل توجهى به اثربخشى روش هاى كيفيت و استانداردسازى در واحدهاى نخهدارى لئ سازمان هاى توليدى بستكى دارد. بر اساس يافته هاى اين مطالعه، نتيجه كيرى مى شود كه صدور گو اهينامها و روش هاى مديريت كيفيت ايزو

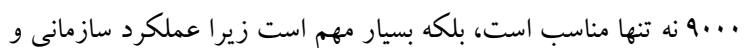
رضايتمندى شر كت هاى توليدى را افزايش مىدهد. در نتيجه اين مطالعه توصيه شد شركت هاى بيشترى از استاندارد ايزو ...9 براى عملكرد و

رضايت استفاده كنند [1ه]. انتخاب يكك سيستم مناسب براى هر صنعت از اهميت ويثه اي برخوردار است. استاندارد ايزو ..9 به عنوان يك استاندارد كيفيت شناخته شده است ليكن فاقد الزامات خاص صنعت مىباشد، در نتيجه بسيارى از بخش هاى صنعتى ضميمه هايى براى استاندارد ايزو توسعه دادند كه براى ويثز گىهاى خاص صنعت خود طر احى و تنظيم شده اند. استاندارد خاص طر احى شده براى صنعت ارتباطات و فناورى اطلاعات، 9000 r مىباشد كه براى تأمين كنندگان و ارائه دهند كان خدمات ارتباطات و فناورى اطلاعات اين امكان را فراهم مى كند كه يك استاندارد جهانى خاص اين صنعت داشته باشند. TL 9000 يك سيستم مدير يت كيفيت است كه براى صنعت ارتباطات و فناورى ارتباطات (ICT) در سال 1991 توسط مئ انجمن QuEST بر مبناى استاندارد ايزو ا ..9 توسعه داده شده است و

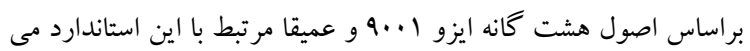
باشد. انجمن QuEST يكك همكارى منحصر به فرد از ارائه دهند كان سرويس و تامين كنندگان ارتباطات و فناورى اطلاعات در سراسر جهان مى باشند كه براى بهبود عملياتى و كيفيت زنجيره تامين و عملكرد آن

\footnotetext{
${ }^{\dagger}$ Polak, Lconard F.\& Kleiner Brian H.

${ }^{\circ}$ Asif khan, M.

${ }^{\&}$ Benchmarking

\author{
'Olonade \& Oyatoye \\ ${ }^{r}$ The Telecom Quality Management System \\ ${ }^{r}$ Pereira et al
}


در حوزه هاى مربوطه مى شوند، با اين حال ادبيات مربوط به مدل هاى

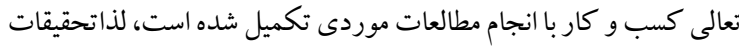

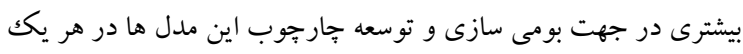
از بخش هاى صنعت و تجارت ضرورى مى باشد [r].

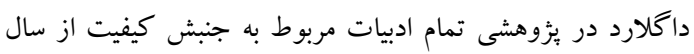

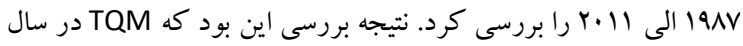

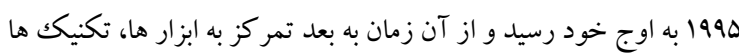
و تعالى كسب و كار مورد توجه قرار كرفت [Yهـ].

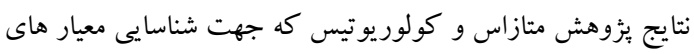

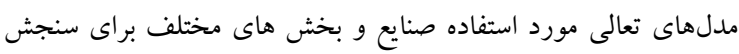

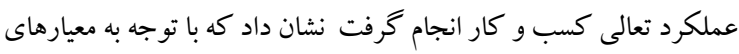

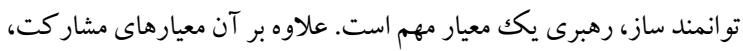
افراد، سياست ها، منابع و استراتزى مدل ها در تمام بخش ها مورد استفاده

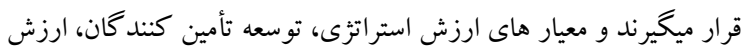

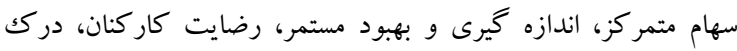
مشترى، نتايج جامعه و نتايج كسب و كار به عنوان معيار هاى اصلى در تمام بخش ها مشهود است. نكته قابل توجه در اين تحقيق اين بود كه توانايى

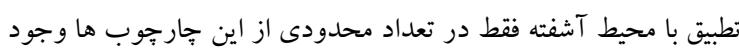

دارد [r]

متازاس و همكاران در بثوهشى به اين نتيجه رسيدند كه نياز به توسعه

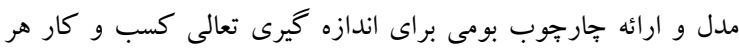
صنعت وجود دارد [ب9]. متازاس و كولوريوتيس در ادامه تحقيق خود با عنوان "اندازه گيرى دولى

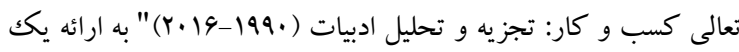

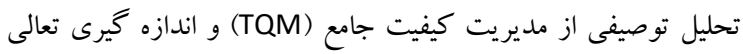

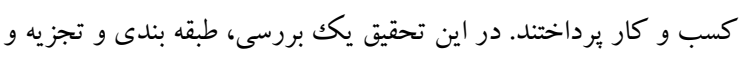

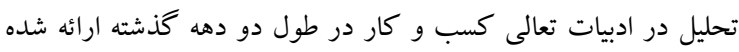
است. در مجموع qجا مقاله از q" مجله مديريت منتشر شده از سال هاى

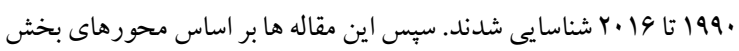
كسب و كار، جارجوب استفاده شده و روش شناسى مورد استفاده،

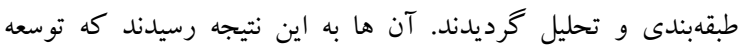

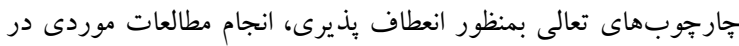
خصوص سنجش اثر بخشى جارجوب هاى تعالى كسب و كار فعلى و

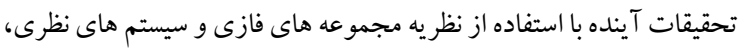
تجزيه و تحليل كلمات كليدى و توسعه و بومى سازى مدل هاى تعالى در

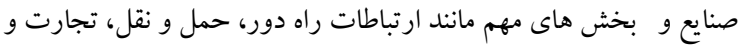
... از طريق مطالعات موردى و تجربى ضرورى مى باشد [ب].
مديريت كيفيت سرويس و تعالى نشان دهد و اقدامات وى بايد به منظور

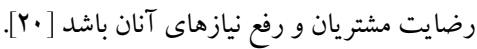

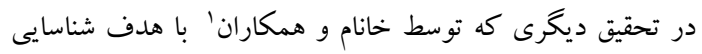
مهم ترين تو انمندسازهاى مديريت كيفيت جامع و منابع فناورى اطلاعات

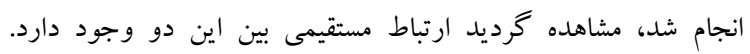

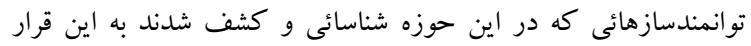

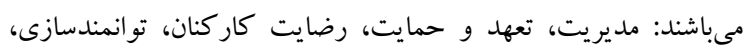

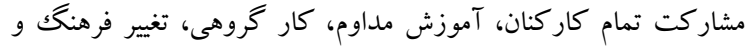

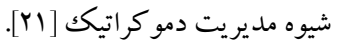

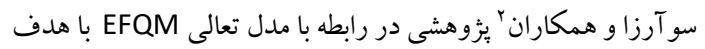

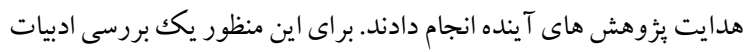

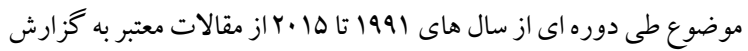
Scimago Journal \& (SJR)

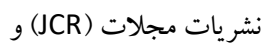
Country Rank انجام شده است. در نهايت بهه مقاله انتخاب شد و جنبه هاى مرتبط با هدف، ابزار و روشهاى جمع آورى داده ها، نوع تجزيه و و تهابل

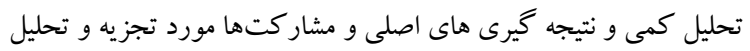

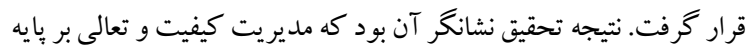

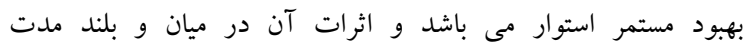

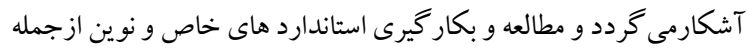

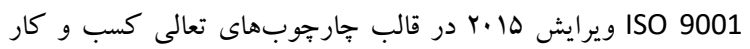
ضرورى مى باشد [rr]

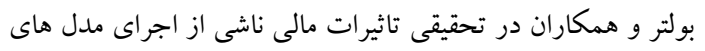

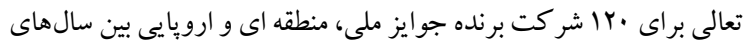

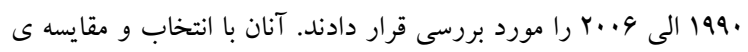
شركت هايى از همان صنعت و كشور بعنوان برنده جايزه به تجزيه و تحليل

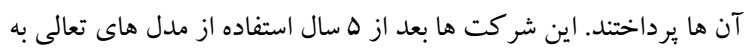

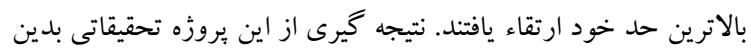

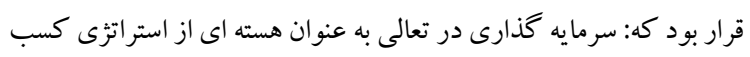

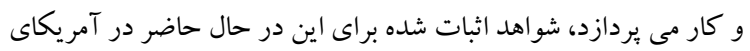

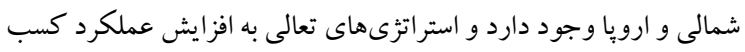
و كار كمكك مى كند [rr]. خان و نعيم در تحقيقى دريافتند كه عوامل نرم افزارى شامل عناصرى

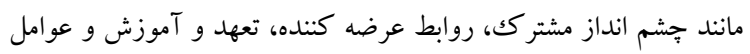
سخت را عناصرى مانند ابزار، تكنيك ها و استاندارد هاى لازم براى روائ كنترل

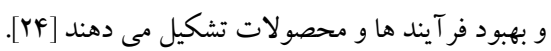

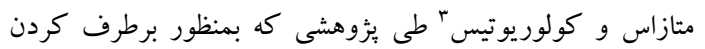

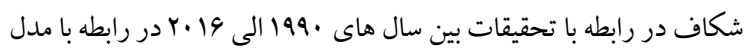

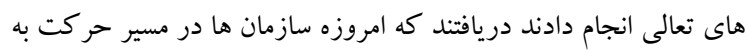

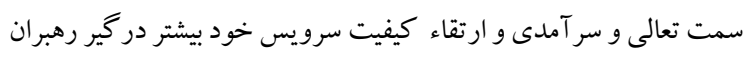


از جمله شكاف هاى تحقيقاتى در اين خصوص مى توان به ضرورت

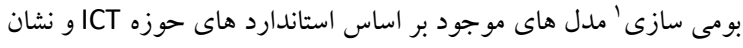

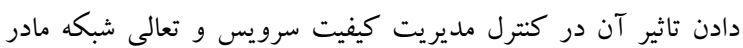

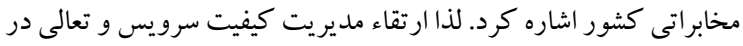

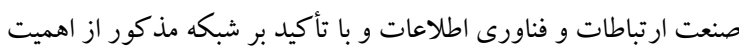
ويثه اي برخوردار است.

\section{ع- شبكه ارتباطات زير ساخت}

شبكه ارتباطات زير ساخت عبارت است از مجموعه سيستم هاى شبكه زيرساخت راه دور و بين الملل مخابرات كشور از جمله مراكز شبكه مايكروويو، شبكه اصلى فيبرنورى بين استانى و ايستكاه هاى زمينى ماهواره

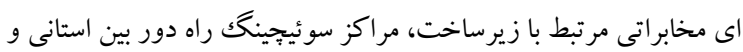

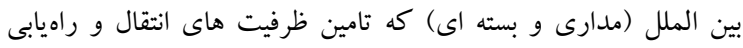

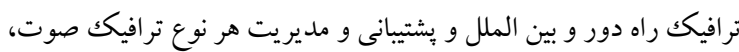
تصوير و داده مورد نياز كشور (إبراتورها، متقاضيان دولتى و غيردولتى، اشخاص حقيقى و حقوقى و نظاير آن) در محدوده بين استانى را برعهده

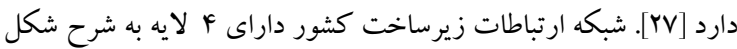
امى باشد.

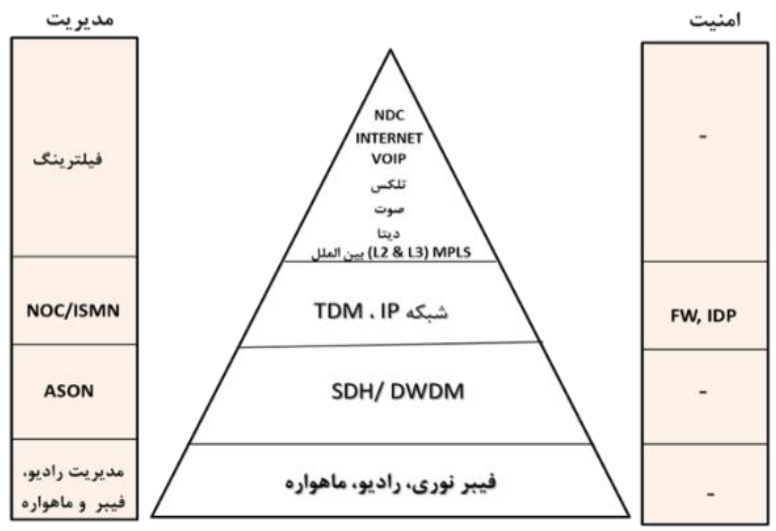

شكل ا: شبكه ارتباطات زيرساخت كشور

اين شـبكه جهت تأمين عرض باند سـرويسـهاى برخط و غيربرخط،

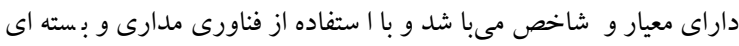

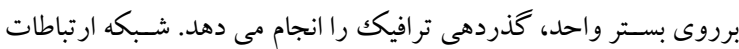

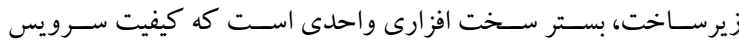

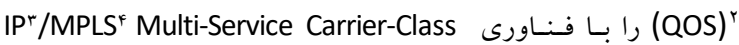
تامين مى كند. عمليات كنترل ترافيك كلى شــبكه، كنترل ازدحام، بايش،

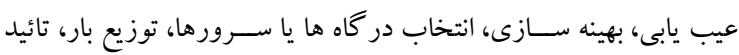
SLA و ضمانت كلاس تجارى روى اين بستر شبكه انجام مى شود.

\section{r- تحليل تحقيقات و شكاف هاى تحقيقاتى}

با بررسى هاى انجام شده و مرور ادبيات موضوع مشاهده مىشود كه

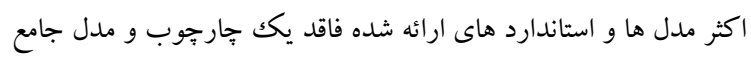

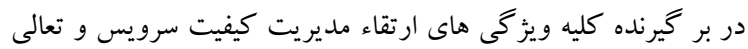
شبكههاى مادر مخابر اتى كشور هستند.

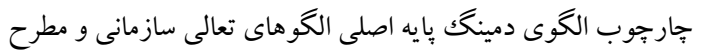

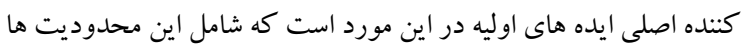

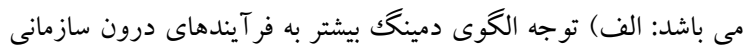

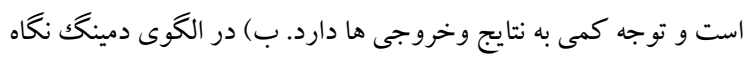

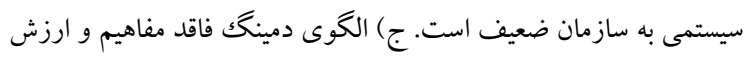

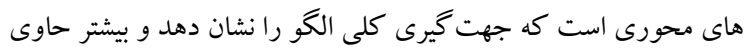

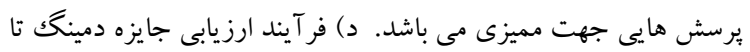

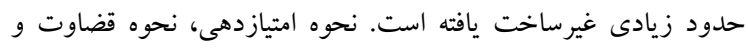

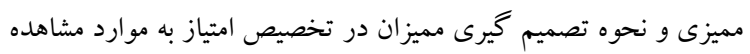
شده به ميز ان زيادى به قضاوت هاى فردى ارزيابان وابسته است.

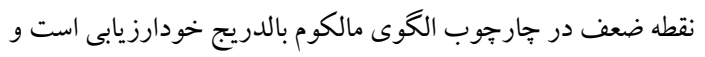
تا زمانى كه سازمان اعطا كننده جايزه تصميم نغيرد كه از اعطاى جايزه

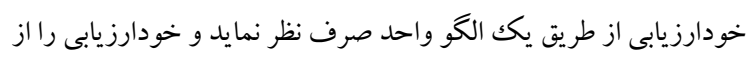

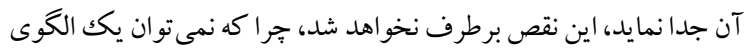

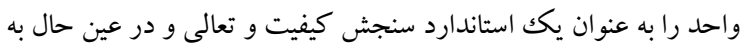

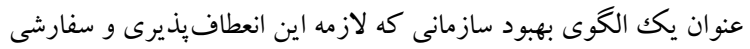
سازى است مورد استفاده قرار داد. يكى از مشكلات استفاده از الكوى EFQM اين است كه توسط دورد

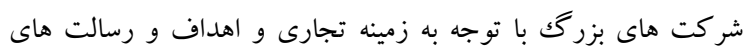

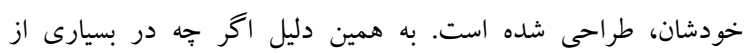

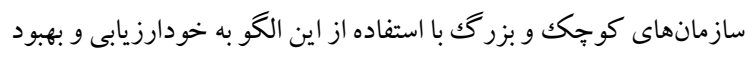

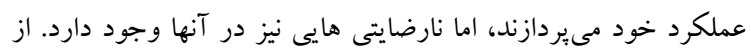

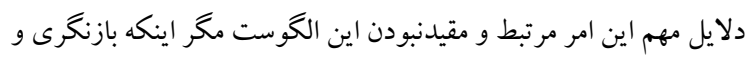
باز آفرينى در آن رخ دهد.

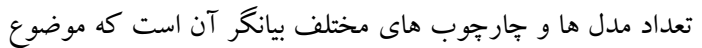

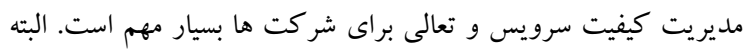

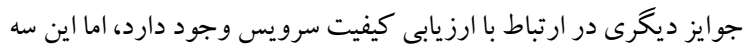
جايزه از اصلى ترين جوايز كيفيت بشمار مى آيند. از سوى ديخر دانستن

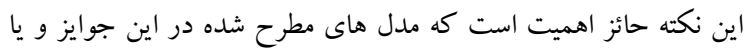

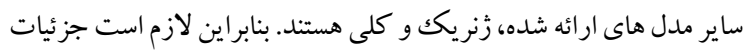

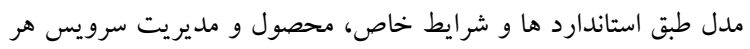
صنعت شكل گرفته و به كار رود.

\footnotetext{
${ }^{*}$ Multiprotocol Lable Switching

- Service Level Agreement

Localization

Quality of Service

r Internet Protocol
} 


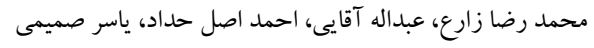

\begin{tabular}{|c|c|c|}
\hline معيار سنجش & عنو ان شاخص & رديف \\
\hline • • • • • • • • • & امكان تجميع OSS و OSSS & 1 \\
\hline 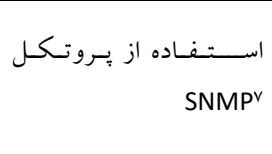 & 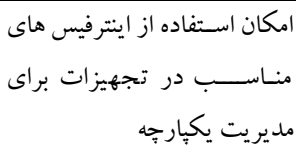 & $r$ \\
\hline مديريت برخط و از راه دور & امكان مديريت منابع & $r$ \\
\hline برقرارى سـرويس ظرف FA & يكهارجه & F \\
\hline 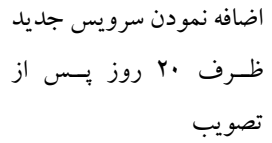 & امكان مديريت توسعه سرويس & $\Delta$ \\
\hline
\end{tabular}

يكِارجه به مفهوم اعمال مديريت يكهارجه در لايه سرويس است و

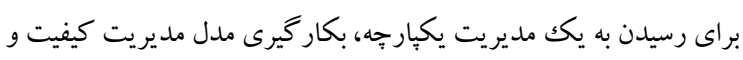

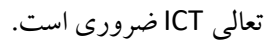

شاخص هاى امنيت شبكه: بر اساس توصيه نامه

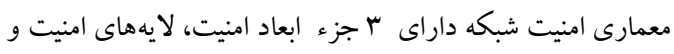

$$
\text { سطوح امنيت مى باشد. }
$$

براى امنيت انتها به انتها، ابعاد امنيت به يكك سلسله مر اتب از تجهيزات

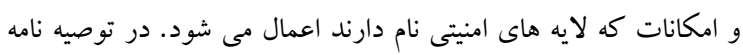

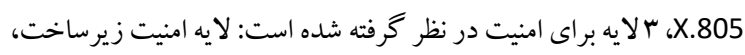

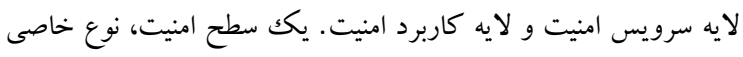

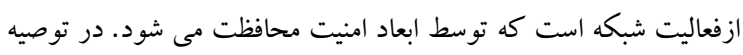

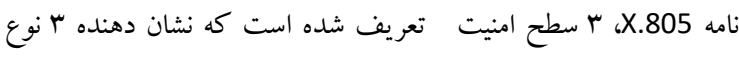
فعاليت حفاظت شده در شبكه مى باشد: سطح مديريت، سطح كنترل و

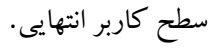

سطوح امنيت نشان دهنده نيازهاى امنيتى خاصى هستند كه به

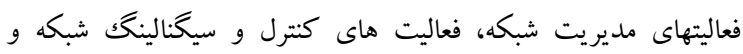

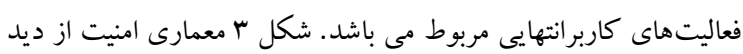

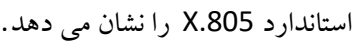
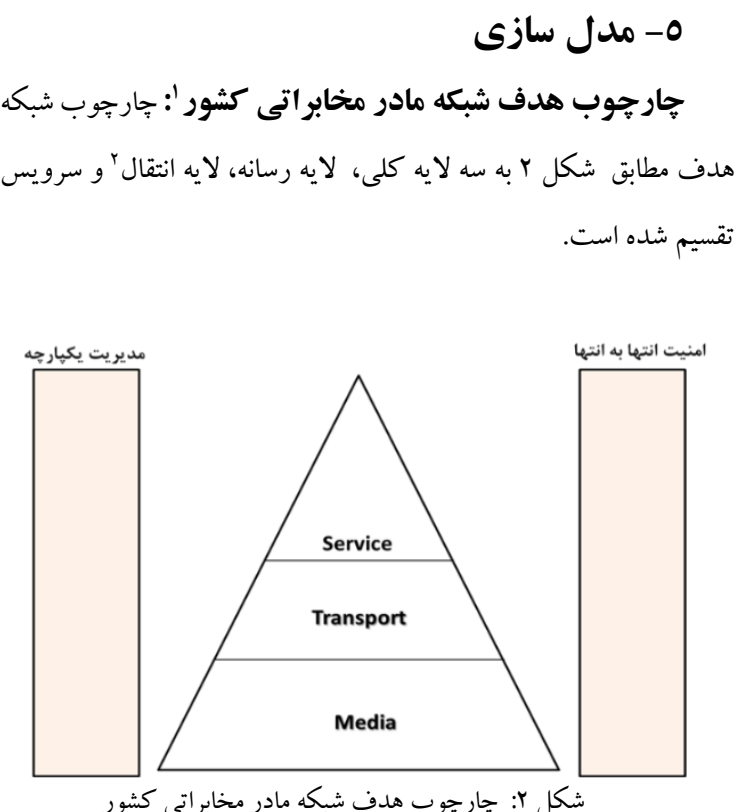

• عملكرد شبكه بر اساس مشترى محورى "ّ: تامين و مديريت

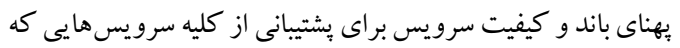
از شبكه درخواست مى شود. مشترى مدارى، تعرفه گذارى و تهيه

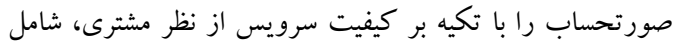
دسترسى آسان، بِايدارى سرويس، امنيت سرويس، سادكى استفاده

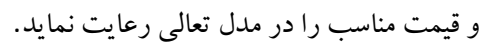
شــاخص هاى كنترلى شــبـكه مادر مخخابراتى كشـــور:

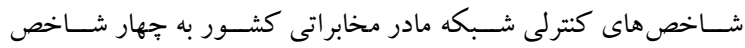

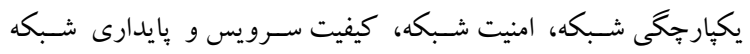
دستهبندى و به دو دسته كلى انتها به انتها و لايه ایى تقسيم بندى شده است

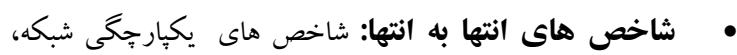
شاخص هاى امنيت شبكه و شاخص هاى بايدارى شبكه. • شاخص هاى لايه اي: شاخص هاى QOS است و در سه لايه مورد كنترل و ارزيابى قرار مى گيرند. • شاخص هاى يكيارجّى شبكه مادر مخابراتى كشور:

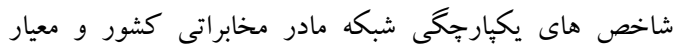

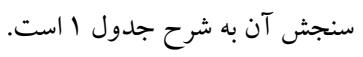

جدول ا: شاخص هاى يكهارجخى شبكه مادر مخابراتى كشور

${ }^{\dagger}$ Operations support systems

${ }^{\triangleright}$ Business Support Systems

${ }^{8}$ Customer Relationship Management

${ }^{v}$ Simple Network Management Protocol
' منابع مطالب نوشته شده در اين بخش در شركت ارتباطات

${ }^{r}$ Transport زيرساخت موجود است.

${ }^{r}$ User-Centric 


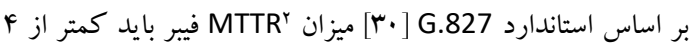

ساعت باشد.

جدول \&: بارامترهاى كارايى در راديو

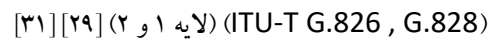

\begin{tabular}{|c|c|c|}
\hline Rate (Mbit/s) & $>55$ to 160 & $(\mathrm{VC}-4, \mathrm{TC}-4) 150,336$ \\
\hline $\mathrm{ESR}^{r}$ & $0.16 \mathrm{~A}$ & $0.04 \mathrm{~A}$ \\
\hline SESR $^{\mathrm{r}}$ & $0.002 \mathrm{~A}$ & $0.002 \mathrm{~A}$ \\
\hline BBER & $0.0002 \mathrm{~A}$ & $0.0001 \mathrm{~A}$ \\
\hline
\end{tabular}

جدول ه: يڤارامترهاى كارايى در ماهواره

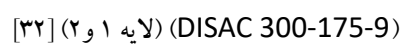

\begin{tabular}{|c|c|}
\hline Performance Parameter & Satellite \\
\hline Line Rate & $50 \mathrm{~K}-50 \mathrm{Mb}$ \\
\hline $\mathrm{EFS}^{\triangleright}$ & $90 \%$ \\
\hline $\mathrm{SES}^{9}$ & $<0.03 \%$ \\
\hline $\mathrm{DM}^{\mathrm{v}}$ & $<2 \%$ \\
\hline $\mathrm{BER}^{\wedge}$ & $1 * 10^{-5}$ or -7 \\
\hline RBER $^{9}$ & $1 * 10^{-5}$ or -7 \\
\hline LBCl' & $1 / 78 \mathrm{hrs}$. \\
\hline Delay & $300 \mathrm{msec}$ \\
\hline Availability & $99.4 \%$ \\
\hline
\end{tabular}

جدول و: شاخص هاى كيفيت سرويس ارتباطات راه دور (لايه Y)زيرساخت

\begin{tabular}{|c|c|c|c|c|c|}
\hline NER $^{\prime f}$ & $\begin{array}{l}\text { AHT } \\
\text { (ثانيه) }\end{array}$ & ضريب & CER $^{1 r}$ & $A B R^{\prime \prime}$ & مبدأ و مقصد \\
\hline $80 \%$ & 90 & - & $90 \%$ & - & SC وارده از SC/PC \\
\hline $80 \%$ & 90 & $99 \%$ & $90 \%$ & $48 \%$ & صادره به SC/PC \\
\hline $88 \%$ & 100 & $99 \%$ & $90 \%$ & $50 \%$ & $\begin{array}{c}\text { صادره به } \\
\text { LX'/TR }^{\prime \prime}\end{array}$ \\
\hline $85 \%$ & 105 & $98 \%$ & $90 \%$ & $50 \%$ & $\begin{array}{c}\text { صادره به } \\
\text { LTX } 19 \text { /TX'. }\end{array}$ \\
\hline $80 \%$ & 60 & $99 \%$ & $90 \%$ & $40 \%$ & صادره به سيار \\
\hline
\end{tabular}

Answer to Bid Ratio

ABR to ASR Ratio (ASR: Answer to Size Ratio)

Average Holding Time

- Network Effectiveness Ratio

Primary Centre

"Secondary Centre

iv Transmit/Receive

'Local Exchange

". Line Transmitter

r. Trnsmitter

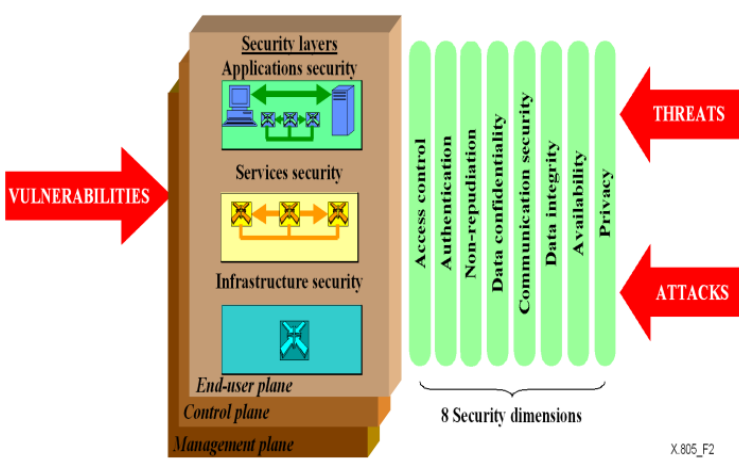

شكل بّ: معمارى امنيت از ديد استاندارد

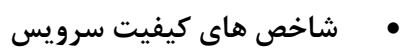

يعنى ارائه سرويس بر اساس كارايى و يا هدف مورد توافق.

ضريب دسترسى و ويارامتر هاى كارايى فيبر، راديو، ماهواره (لايه

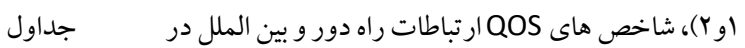

r الى V Vشان داده شده است.

جدول r: ضريب دسترسى در فيبر (لايه او r)

با توجه به يَارامترهاى SLA زيرساخت

\begin{tabular}{|c|c|c|}
\hline مدت قطعى مجاز در ماه & ضريب دسترسى (درصد) & SLA \\
\hline r r د دقيقه & 99 & برنز ان \\
\hline T & $99 / 4$ & نقره \\
\hline r & $99 / 9$ & bل \\
\hline ثانيه Y Y & $99 / 99$ & 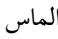 \\
\hline
\end{tabular}

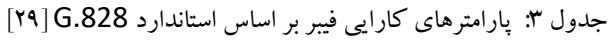

\begin{tabular}{|c|c|c|}
\hline Bit rate (Kbit/s) & Path type & BBER' $^{\prime}$ \\
\hline 2240 & VC-12, TC-12 & $5 \times 10^{-5}$ \\
\hline 150336 & VC-4, TC-4 & $1 \times 10^{-4}$ \\
\hline 601344 & VC-4-4c, TC-4-4c & $1 \times 10^{-4}$ \\
\hline 2405376 & VC-4-16c, TC-4-16c & $1 \times 10^{-4}$ \\
\hline 9621504 & VC-4-64c, TC-4-64c & $1 \times 10^{-3}$ \\
\hline
\end{tabular}

' Background Block Error Ratio

- Mean Time To Repair

Errored Second Ratio

Severely Errored Second Ratio

Error Free Seconds

'Severely Errored Seconds

Degraded Minutes

Bit Error Rate

${ }^{9}$ Residual Bit Error Rate

Loss of Bit Count Integrity 


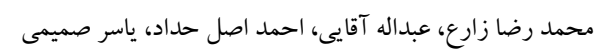

\begin{tabular}{|c|c|c|c|c|c|}
\hline $\begin{array}{l}\text { Transaction data, } \\
\text { highly interactive } \\
\text { (signaling) }\end{array}$ & N & & & & \\
\hline High quality services & $\checkmark$ & $\begin{array}{l}8 \\
0 \\
0\end{array}$ & $\xi$ & 긍 & $\begin{array}{l}Y_{0} \\
\dot{0}\end{array}$ \\
\hline
\end{tabular}

شاخص هايدارى: بايدارى به معنى قابليت موجود بودن يك

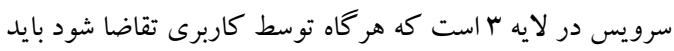

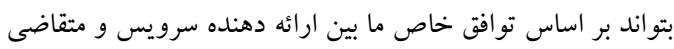

$$
\text { سرويس ارائه كردد. }
$$

براى رسيدن به شاخص بايدارى CIR يا بِهناى باند تضمين شده

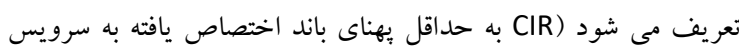

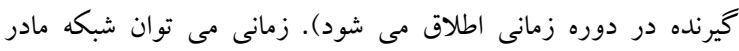

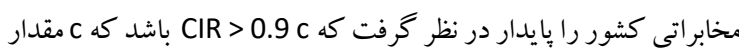

$$
\text { مورد توافق بين سرويس كيرنده و فراهم كننده سرويس است. }
$$

\section{مدل مديريت سرويس شبكه مادر مخابر اتى كشور}

كيفيت سرويس عنصرى ضرورى و موردنظر براى تفاوت كذارى بين سرويس هايى است كه به جذب و مديريت مشترى مى بردازد و حركت كت برون

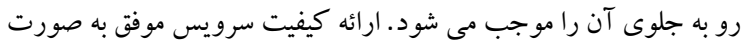

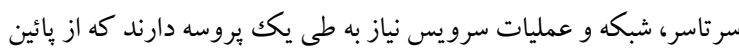

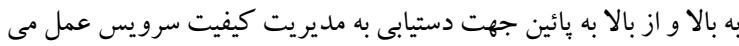

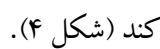

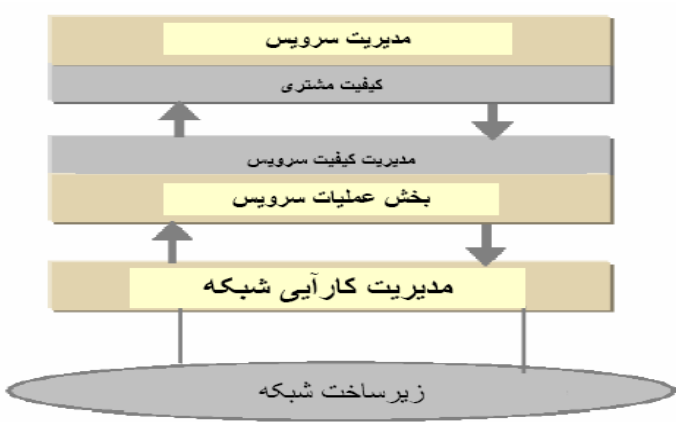

شكل ٪: يروسه ارائه مديريت سرويس شبكه مادر مخابراتى كشور

مدل مديريت سرويس شبكه مادر مخابراتى كشور با هدف ارتقاء

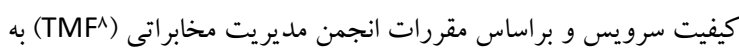

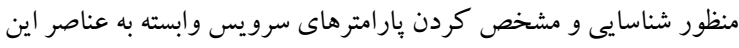

\begin{tabular}{|c|c|}
\hline ينجن تا هشت ساعت (نرمال)، بيش از هشت ساعت & $\begin{array}{l}\text { كار كرد كانال در روز (ساعت) } \\
\text { كاع) }\end{array}$ \\
\hline
\end{tabular}

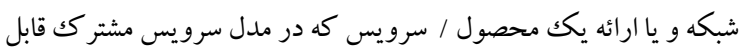

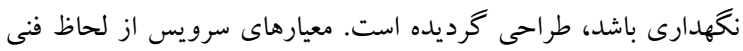

\begin{tabular}{|c|c|c|c|c|c|}
\hline \multicolumn{6}{|c|}{ زيرساخت } \\
\hline $\begin{array}{c}\mathrm{NE} \\
\mathrm{R}\end{array}$ & $\begin{array}{l}\text { AHT } \\
\text { (ثانيه) }\end{array}$ & ضريب & CER & ABR & مبدأ و مقصد \\
\hline - & 90 & $98 \%$ & - & - & كشور \\
\hline - & 100 & $99 \%$ & - & - & 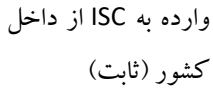 \\
\hline - & 80 & $99 \%$ & - & - & 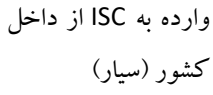 \\
\hline $\begin{array}{r}70 \\
\%\end{array}$ & 90 & $98 \%$ & $85 \%$ & $27 \%$ & كشور \\
\hline $\begin{array}{r}85 \\
\%\end{array}$ & 150 & $99 \%$ & $95 \%$ & $45 \%$ & 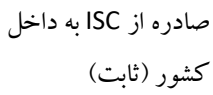 \\
\hline $\begin{array}{r}75 \\
\%\end{array}$ & 90 & $99 \%$ & $85 \%$ & $27 \%$ & 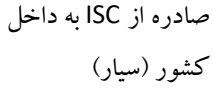 \\
\hline
\end{tabular}

جدول V: شاخص هاى كيفيت سرويس ارتباطات بين الملل (لايه Y)

ضريب دسترسى مشخص كننده امكان دسترسى سرويس گيرنده به حداكثر سرويس هاى ارائه شده روى بستر شبكه سرويس دهنده با توجه به

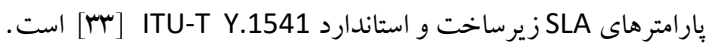
يارامتر هاى كارايى و قابليت دسترسى در لايه بـ در جدول ^ منشان داده

\begin{tabular}{|c|c|c|c|c|c|c|}
\hline كثالى از & 然 & $\begin{array}{l}\xi \\
\xi \\
\xi \\
\xi \\
\xi\end{array}$ & $\stackrel{\sim}{\Sigma}$ & 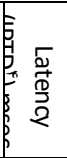 & 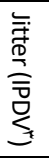 & 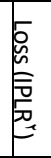 \\
\hline $\begin{array}{l}\text { Low loss only (short } \\
\text { transaction, bulk } \\
\text { data, video } \\
\text { streaming) }\end{array}$ & $\triangle$ & \multirow[t]{2}{*}{$\wp_{\infty}$} & \multirow{2}{*}{ : } & \multirow{2}{*}{$\begin{array}{l}\stackrel{\bullet}{\circ} \\
\stackrel{1}{\bullet} \\
\stackrel{0}{0}\end{array}$} & \multirow{2}{*}{$\begin{array}{l}\text { No } \\
\text { ஸे } \\
\text { Uั }\end{array}$} & \multirow{5}{*}{$\begin{array}{l}\qquad \\
x \\
\stackrel{\bullet}{0} \\
\dot{\omega} \\
\omega\end{array}$} \\
\hline $\begin{array}{c}\text { Traditional } \\
\text { applications of default } \\
\text { IP network }\end{array}$ & u & & & & & \\
\hline $\begin{array}{c}\text { Real-time, jitter } \\
\text { sensitive, interactive } \\
\left(\text { VolP }^{\diamond}, \mathrm{VTC}^{\varsigma}\right)\end{array}$ & $\vdash$ & \multirow[t]{2}{*}{$\bullet$} & \multirow[t]{2}{*}{$\dot{c}_{0}^{0}$} & \multirow{2}{*}{$\begin{array}{l}\text { ज़ } \\
\stackrel{5}{\circ}\end{array}$} & \multirow{2}{*}{$\begin{array}{l}\text { v } \\
\dot{\sim}\end{array}$} & \\
\hline $\begin{array}{l}\text { Transaction data, } \\
\text { interactive }\end{array}$ & $\omega$ & & & & & \\
\hline $\begin{array}{l}\text { Real-time, jitter } \\
\text { sensitive, high } \\
\text { interaction (VolP, } \\
\text { VTC) }\end{array}$ & 0 & $\begin{array}{l}\text { b } \\
\text { in }\end{array}$ & $\check{r}$ & $\begin{array}{l}\text { ज } \\
\dot{1} \\
\text { जั }\end{array}$ & 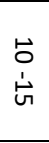 & \\
\hline
\end{tabular}
شده است.

جدول من پِارامتر هاى كارايى و قابليت دسترسى (لايه ب) زيرساخت

' International Switching Centre

'Internet Protocol Packet Loss Ratio

${ }^{r}$ Internet Protocol Packet Delay Variation

^ Internet Protocol Packet Transfer Delay 
مدل مدير يت كيفيت و تعالى ارتباطات و فناورى اطلاعات با توجه به مديريت سرويس و ابعاد مختلف آن از جمله شرايط خاص و استاندارها،

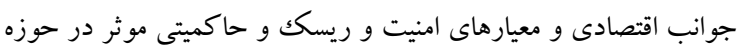
ICT

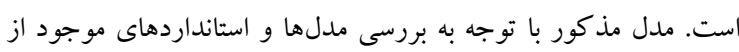

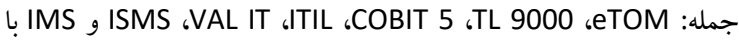
بهره گيرى از آخرين ويرايش مدل كيفيت ارويا بومىسازى شده است. شكل هاى لو ^ ^به ترتيب سطوح و ارتباط بين استانداردهاى حوزه ICT و مدل تعالى طراحى شده را نشان مى دهند.

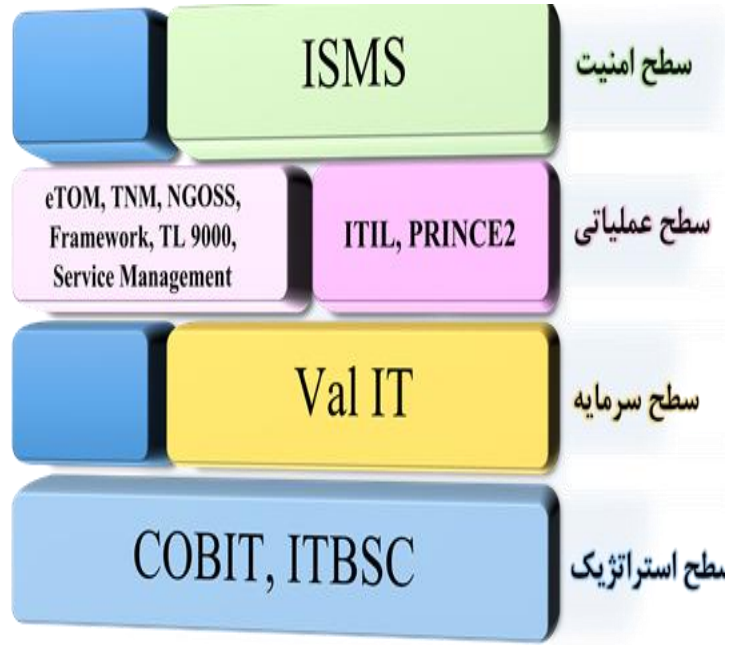

شكل V: سطوح و ارتباط بين مدل ها و استانداردهاى حوزه ICT

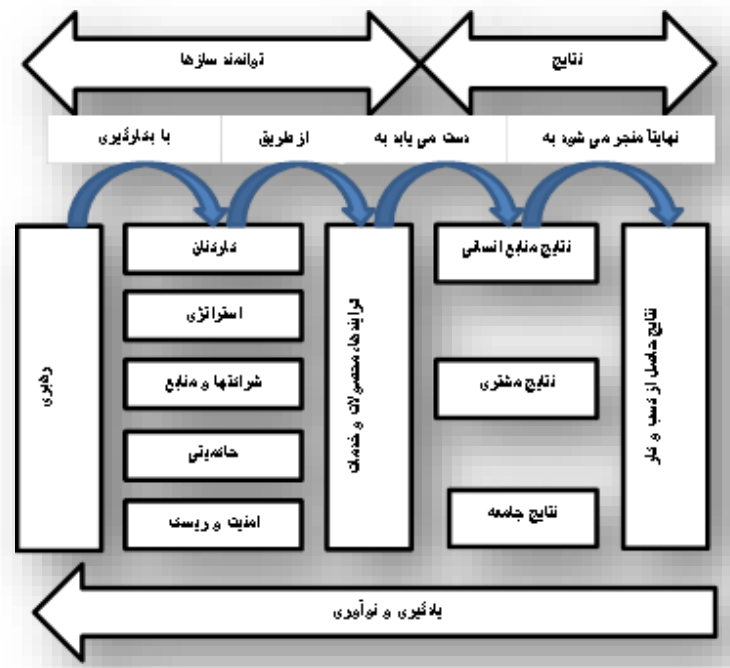

شكل من مدل مديريت كيفيت و تعالى ICT

1- إستاوردهاى يزوهش
شاخص هاى كليدى كارايى (KPI') مىباشند كه از شبكه مذكور حاصل

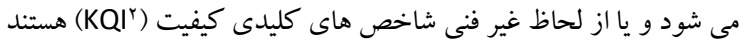
كه به مشترى مربوط مى شود. يكك محيط مدل سرويس مشتر كى، امكان

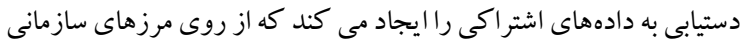

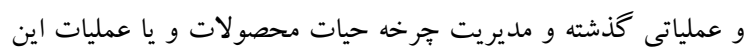

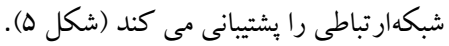

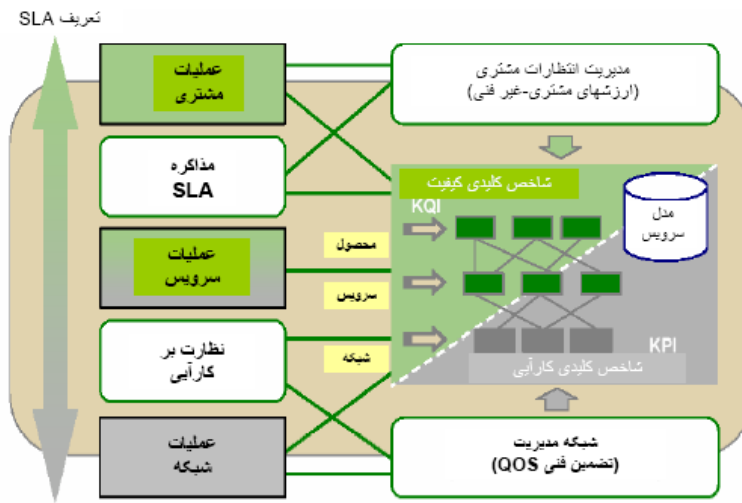

KPرين

شكل ه: محيط مدل مديريت سرويس شبكه مادر مخابراتى كشور مدل سرويس از يكك شيوه نظام مند جهت ارزيابى عمليات سرويس و

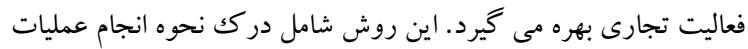

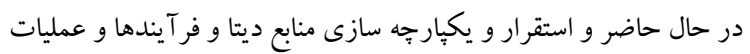
مرتبط با بروزسازى سرويس ها و محصولات جديد مى شود. اين مدل از

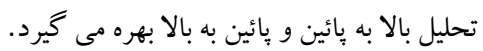
بلو كك هاى ساختمانى مديريت سرويس در شكل 9 نشان داده شده

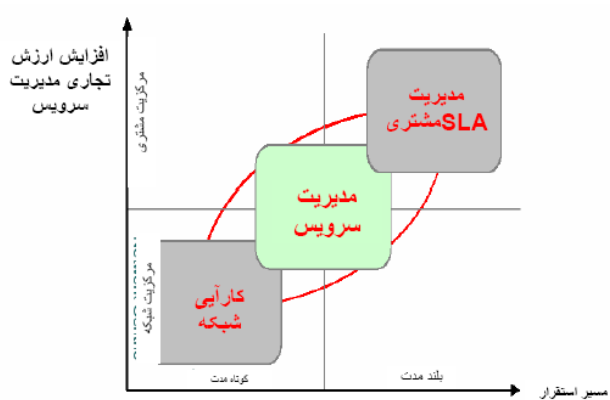

شكل 9: بلو كهاى ساختمانى مديريت سرويس

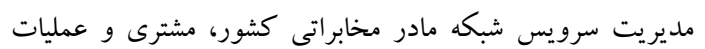

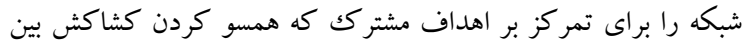
شبكه و مشترى است را يكِارجه مى سازد.

مدل مديريت كيفيت و تعالى ارتباطات و فناورى اطلاعات 
ICT

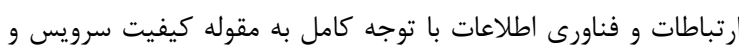

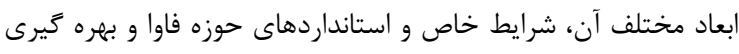

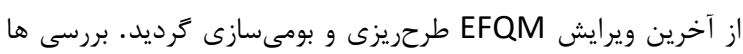

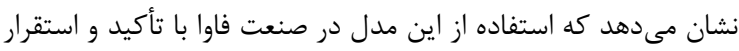

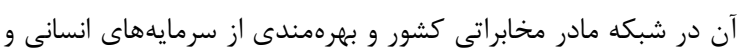

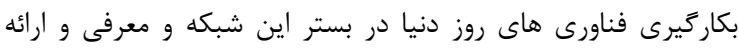

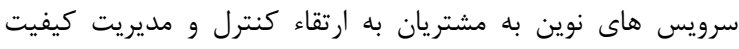

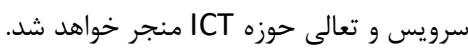

\section{مراجع}

[1] Grigg, N., Mann, R., Promoting excellence: An international study into creating awareness of business excellence models, The TQM Journal, 20(3), 2008, 233-248.

[2] Ioannis N. Metaxas, Dimitrios E. Koulouriotis (2017) "Business excellence measurement: a literature analysis (1990-2016)”, Total Quality Management \& Business Excellence.

[3] Ferguson, Pannirselvam, G. P, L. A., A study of the relationships between the Baldrige categories, International Journal of Quality and Reliability Management, Vol 18, No.1, 2001, pp.14-34.

[4] Saladin, B., Flynn, B., Further evidence on the validity of the theoretical models underlying the Baldrige criteria, Journal of Operations Management, Vol. 19, No. 6, 2001, pp. 617-52.

[5] Lee, S.M., B.H., Rho, S.G., Lee, Impact of Malcolm Baldrige national quality award criteria on organizational quality performance, International Journal of Production Research, 41: 2003-2020, 2003.

[6] Calvo-Mora, A., Picón-Berjoyo, A., Ruiz-Moreno, C., Cauzo-Bottala, L., The relationships between soft-hard TQM factors and key business results, International Journal of Operations \& Production Management, 34(1), 2014, 115-143.

[7] Mohammad, M., National Quality/Business Excellence Awards in different countries, Retrieved from http://www.nist.gov/, 2010.

[8] ITU-T Recommendation M.3050.2 Enhanced Telecom Operations Map (eTOM) - Process decompositions and descriptions,2004

[9] GB921, T. (2004). Enhanced Telecom Operations Map (eTOM)-The business process framework: Approved Version 4.0, TM Forum Guidebook, from www.tmforum.org.

[10] Lu, Hanhua, et al., OSS/BSS Framework Based on NGOSS, Chengdu, China 2010.

$$
\text { - }
$$

\section{Y- جمع بندى و نتيجه كيرى}

با بررسى مقالات مختلف دريافتيم كه مدل ها، خارجوب ها و

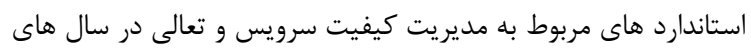

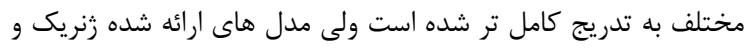
كلى هستند.

نكته مشترك در اين مدل ها براى ارائه سرويس با كيفيت بهتر، اين

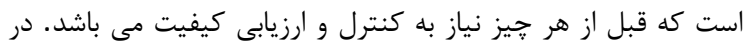

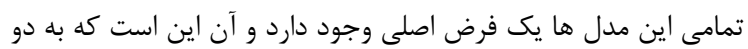
حوزه توانمندسازها و نتايج تقسيم مى مل شوند. كنترل و ارزيابى عملكرد يكى از مههم ترين ابزار ها جهت اندازهيرى

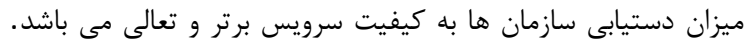

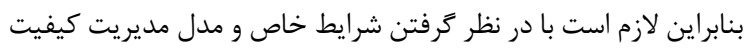

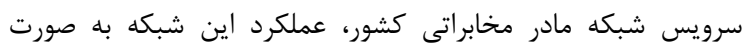

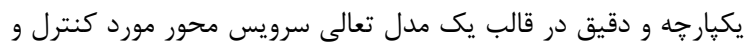

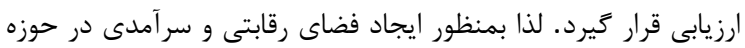

'- Stakeholders 
"Quantitative research on the EFQM excellence model: A systematicliterature review (19912015)" European Research on Management and Business Economics, IEDEEN-23; No. of Pages 10.

[23] Boulter, L., Bendell, T. \& Dahlgaard, J.J. (2013). Total quality beyond North America: A comparative analysis of the performance of European Excellence Award winners. International Journal of Operations and Production Management, 33(2).

[24] Khan, B. A., \& Naeem, H. (2016). Measuring the impact of soft and hard quality practices on service innovation and organisational performance. Total Quality Management \& Business Excellence, doi:10.1080/14783363.2016.1263543.

[25] Dahlgaard-Park, S. M., Chen, C.-K., Jang, J.-Y., \& Dahlgaard, J. J. (2013). Diagnosing and prognosticating the quality movement - a review on the 25 years quality literature (1987-2011). Total Quality Management \& Business Excellence, 24(1-2), 1-18

[26] Metaxas, I. N., Koulouriotis, D. E., \& Spartalis, S. H. (2016). A multicriteria model on calculating the Sustainable Business Excellence Index of a firm with fuzzy AHP and TOPSIS. Benchmarking: An International Journal, 23(6), 1522-1557.

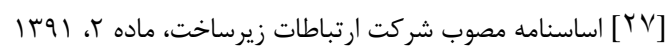

[28] ITU-T X.805 Standard, https://www.itu.int/rec/TREC-X.805, 2003

[29] ITU-T G.828 Standard, https://www.itu.int/rec/TREC-G.828-200003-I/en, 2001

[30] ITU-T G.827 Standard, https://www.itu.int/rec/TREC-G.827-200309-I/en, 2004

[31] ITU-T G.826 Standard, https://www.itu.int/rec/TREC-G.826-200212-I/en, 2003

[32] DISAC 300-175-9 - Defense Information Systems Agency, http://www.disa.mil/ / media/Files/DISA/About/Publication/Circular/dc3 001759_basic-chng1.pdf, 2009

[33] ITU-T Y.1541 Standard, https://www.itu.int/rec/TREC-Y.1541-200205-S/en, 2012
[11] Lee, D., Lee, D. H., A comparative study of quality awards: Evolving criteria and research. Service Business, 7, 2012, 347-362.

[12] Joaquin Gomez Gomez, Micaela Martinez costa, angel R. Martinez lorente (2017) "EFQM Excellence Model and TQM: an empirical comparison" Total Quality Management \& Business Excellence, Vol. 28, No. 1, 88-103.

[13] Ulas Akkucuk., Yasin Galip Gencer (2017) "EFQM Model and Sustainability of Organizations" International Conference on Advances in Management Engineering and Information Technology, ISBN: 978-1-60595-4578 .

[14] Marina Godinho Antunes, Joaquín Texeira Quirós, Maria do Rosário Fernandes Justino, (2017) "The relationship between innovation and total quality management and the innovation effects on organizational performance" International Journal of Quality \& Reliability Management, ISSN: 0265$671 X$.

[15] Paul Olanrewaju Olonade. Emmanuel Olateju Oyatoye, (2017) "ISO 9000 and quality standards improvemence units of selected manufacturing firms in LAGOS" JORIND 15(1)June, 2017. ISSN 1596-8303.

[16] Uma, Chandrashekhar.,Scott, Nelson., Delivering Network Assurance Through Secure and Reliable Solutions, 2012.

[17] Pereira, Cristiano, Ferreira, Carlos, Amaral, Luis, (2017) "IT Value Management Capability Enabled with COBIT 5 Framework" European, Mediterranean, and Middle Eastern Conference on Information Systems, pp 431-446.

[18] Polak, Leonard F., Kleiner, Brian H., Managing for Excellence in the Telecommunication Industry, Volume 23, 2000.

[19] Asif Khan, M., Evaluating the Deming Management Model of Total Quality in Telecommunication Industry in Pakistan - An Empirical Study, Vol. 5, No. 9, International Journal of Business and Management, www.ccsenet.org/ijbm, 2010.

[20] Talib, F., Rahman, Z., Qureshi, M.N., An empirical investigation of relationship between total quality management practices and quality performance in Indian service companies, International Journal of Quality and Reliability Management (IJQRM), Emerald Publishers, Vol. 30, No.3, 2013, 280-318.

[21] Khanam, S., Siddiqui, J., Talib, F., Modeling the TQM enablers and IT resources in the ICT industry: an ISM-MICMAC approach, Int. J. Information Systems and Management, Vol. 1, No. 3, 2015, 195.

[22] Eva Suáreza, Arturo Calvo-Morab,*, José L. Roldánb, Rafael Periánez-Cristóbal, (2017) 